\title{
Exploration Geology of the Luxinga Kimberlite Cluster (Angola) with Evidence Supporting the Presence of Kimberlite Lava
}

\author{
R. Eley ${ }^{1}$, H. Grütter ${ }^{2}$, A. Louw ${ }^{3}$, C. Tunguno ${ }^{4}$, J. Twidale ${ }^{1}$ \\ ${ }^{1}$ BHP Billiton World Exploration, 6 Hollard Street, Marshalltown 2001, Johannesburg, South Africa \\ ${ }^{2}$ BHP Billiton World Exploration, \#800 Four Bentall, 1055 Dunsmuir Street, Vancouver, B.C., V7X 1L2, Canada \\ ${ }^{3}$ MSA Geoservices, 20b Rothesay Ave, Craighall Park, Johannesburg, 2120, South Africa \\ ${ }^{4}$ Projecto Alto Cuilo, Rua Comandante N'Zagi 68/68A, Bairro Alvalade, Luanda, Angola
}

\section{Introduction}

Airborne magnetic surveys conducted over the Alto Cuilo project in Lunda Sul province, NE Angola (Fig. 1) have formed the basis of diamond exploration during December 2004 to May 2008 under the auspices of a joint venture between BHP Billiton, Petra Diamonds, Endiama and Moyoweno. Fixed-wing and helicopter-based airborne surveys highlighted over 200 separate anomalies of possible kimberlite against the extremely quiet magnetic background of TriassicJurassic Karoo sediments. Narrow diameter core drilling and accompanying data acquired from 80 Cretaceous kimberlites across the concession has established the presence of two geomagnetically distinct kimberlite clusters, of which the Luxinga cluster, located in the NE of the concession, is described in this work.

\section{Exploration Methodology}

Kimberlite at Alto Cuilo is covered by an average of 50m of Cretaceous Calonda and Quaternary Kalahari Formation, implying that successful exploration is underpinned by the results of a fixed-wing, $200 \mathrm{~m}$ linespaced airborne magnetic (AM) survey flown in April 1998, followed by a high-resolution helicopter-based $100 \mathrm{~m}$ line-spaced survey completed in July 2005. Given background lithologies contribute effectively no magnetic noise, the 2005 AM survey proved to have sufficient spatial resolution to site drill targets on possible kimberlite without the requirement of additional ground magnetic surveys. All AM targets over $5 \mathrm{Ha}$ were prioritized for exploratory $\mathrm{NQ}$ core drilling. Up to fifteen holes were drilled per AM target, depending on site access, target size, varied geomagnetic texture, drilling success and the extent and thickness of crater-facies kimberlite units encountered. Handheld magnetic susceptibility readings were taken at $1 \mathrm{~m}$ intervals along core from

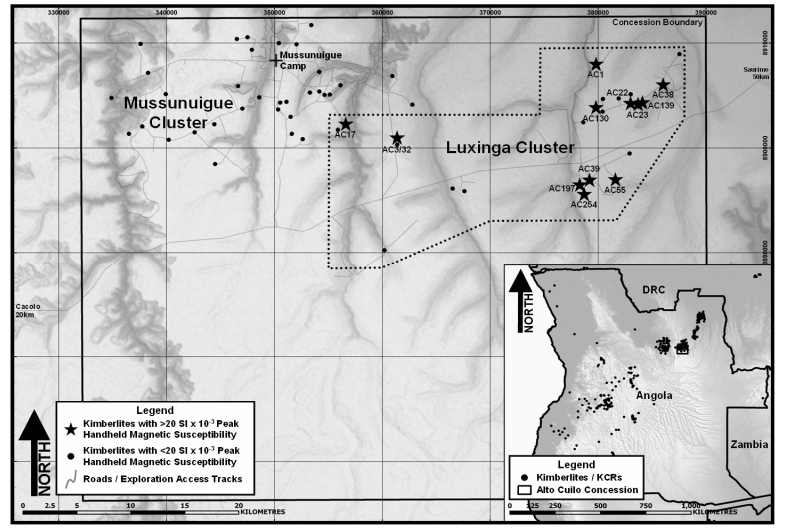

Fig. 1 Location map showing the distribution of 57 of the 80 kimberlites at Alto Cuilo, highlighting the 12 bodies with $>20$ SI $\times 10^{-3}$ peak magnetic susceptibility values characterizing the geomagnetically distinct Luxinga Kimberlite Cluster

every drillhole (magnetic logging). Such data are available for 57 of the 80 drill-confirmed kimberlites and provide invaluable data to assist facies mapping and geological modeling of the AM target and its' overall geometry within host rocks. Magnetic logging also supported collection of representative core samples for independent petrographic, indicator mineral and microdiamond analysis. Results for these ancillary studies are described in a related contribution to the 9IKC (Rogers et al, 2008) and in news releases by Petra Diamonds (www.petradiamonds.com) An extensive alluvial diamond exploration program provided useful corroborative data on diamond quality and distributions across the concession.

Identifying the Geomagnetic Footprint of the Luxinga Kimberlite Cluster

The 2005 AM survey showed high-amplitude magnetic anomalies clustered in the eastern sector of Alto Cuilo (Luxinga area, Fig. 1), in contrast to subtle, low-

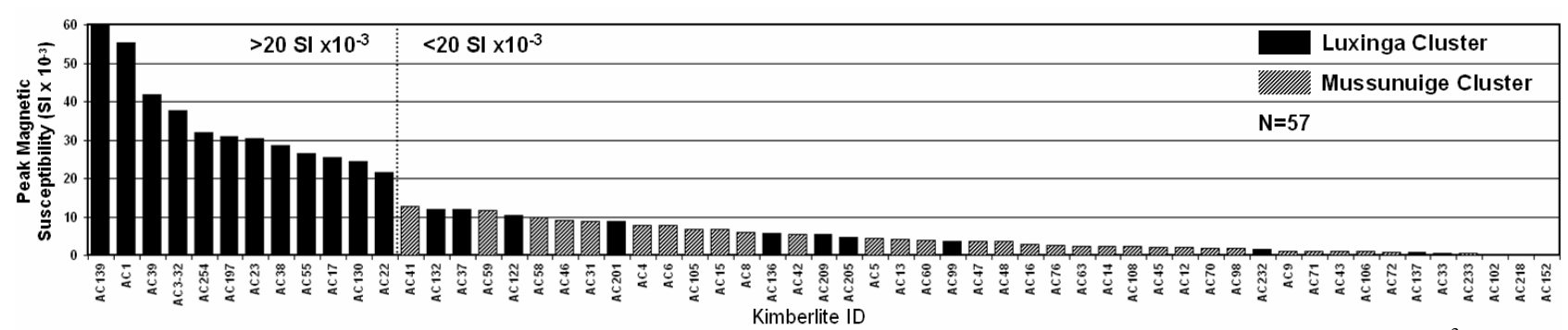

Fig. 2 Peak handheld magnetic susceptibility values for 57 of the 80 kimberlites at Alto Cuilo, showing the 20 SI x $10^{-3}$ cut-off described in this poster, and the location of each body within the Mussunuige or Luxinga kimberlite clusters. 


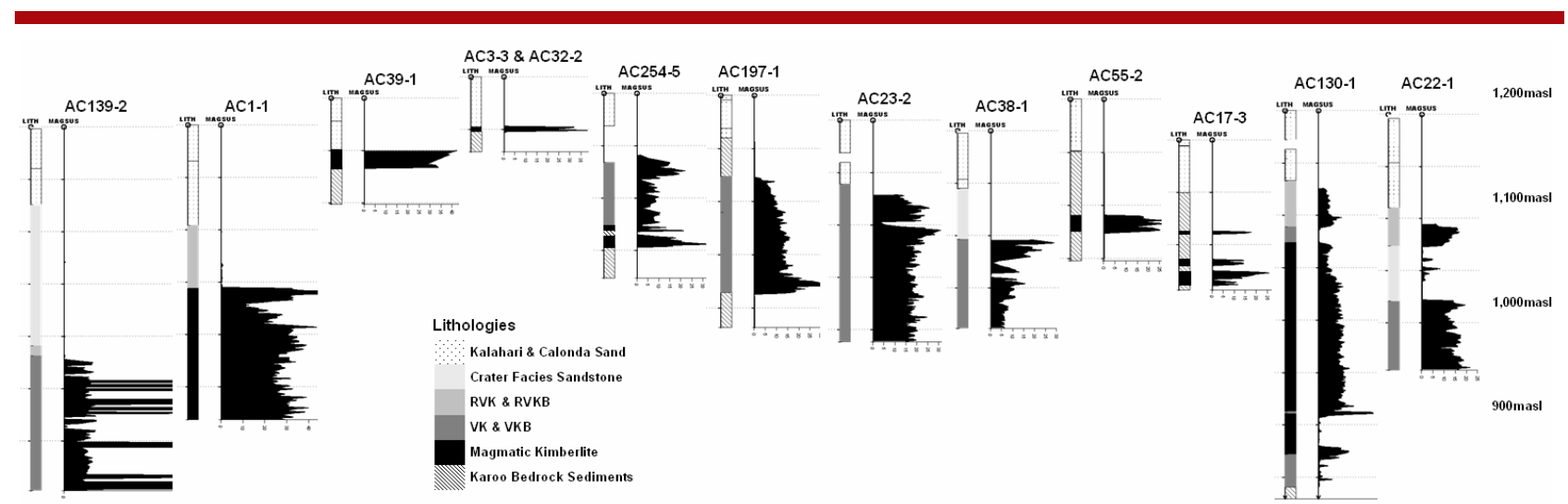

Fig. 3 Downhole lithology \& magnetic susceptibility profiles for the 12 bodies with $>20$ SI $\times 10^{-3}$ peak magnetic susceptibility values. Drillholes are illustrated left to right with decreasing peak values; elevation (masl) is shown to scale on the right.

amplitude anomalies in the central and western sectors of the concession (Mussunuige area, Fig. 1) It was inferred that the Luxinga-area magnetic targets were closer to surface (i.e. thinner overlying cover sediments) than elsewhere. However, exploration drilling revealed that overburden thicknesses were consistent across the whole concession, but that the Luxinga kimberlite core routinely had significantly higher magnetic susceptibility. Compared to all available results (Fig. 2), we use a peak magnetic susceptibility value of $20 \times 10^{-3}$ SI units as an empirical cut-off to map the geographical extent of the Luxinga kimberlite cluster. We observe that the top-12 highly magnetic kimberlites at Alto Cuilo are located in this cluster and thereby establish a distinct Luxinga-type geomagnetic footprint (Fig. 1, Fig. 2 \& Fig. 3)

\section{Kimberlite Intrusion Ages}

Accurate age data for Angolan kimberlites are very rare, in part due to pervasive secondary alteration of the bodies. The kimberlites at Alto Cuilo proved no exception in this regard, but our persistent efforts produced accurate data for 10 kimberlites, including 5 from the Luxinga area. Phlogopite $\mathrm{Rb}-\mathrm{Sr}$ and perovskite or zircon $\mathrm{U}-\mathrm{Pb}$ ages (Table 1) range from $145 \mathrm{Ma} \pm 4.0 \mathrm{Ma}$ (early Cretaceous) for highsusceptibility Luxinga-type kimberlite to $113 \mathrm{Ma}$ $\pm 0.8 \mathrm{Ma}$ (mid Cretaceous) for low-susceptibility kimberlites. The four oldest kimberlites are located within the Luxinga cluster, along with 3 younger bodies, implying overlapping geomagnetic footprints exist through time. Although only 10 kimberlites at Alto Cuilo have accurate emplacement age data, relative ages for the remaining kimberlites can be inferred by noting the position of the dated kimberlites within the local stratigraphy: the 140 Ma-old kimberlites occur at the base of, and are overlain by, the Cretaceous Calonda Formation, the mid-Cretaceous kimberlites occur at various elevations through the unit, and the youngest kimberlites cut across the entire preserved section of the Calonda Formation, and are overlain by the base of the Quaternary Kalahari Formation.

\section{Kimberlite Eruption and Presence of Lava}

Minimal post-eruptive erosion of the Luxinga kimberlites has led to the preservation of crater facies deposits that typically are absent at many kimberlites providing a unique opportunity to observe and interpret the environments that host the products of kimberlite eruptions. Kimberlite vents predominate as the main product of eruption at Alto Cuilo (Class 1 and 2 pipes of Skinner, 2004) However, a significant quotient of shallow intrusive (dykes \& sills) and rarer extrusive (lava) magmatic kimberlite products are noted as characteristic of the Luxinga cluster. Kimberlite $\mathrm{AC} 3 / 32$ (Fig. 4) is interpreted as an extrusive lava flow and $\mathrm{AC} 1$ (Fig. 5) as a vent-filling lava lake.

Kimberlites of all ages at Luxinga have undergone minimal erosion - even the older kimberlite pipes that are completely overlain by Cretaceous sediments have thick (recorded to a depth of over $500 \mathrm{~m}$ ) sand-diluted crater facies units of material that slumped back into the open craters from the volcanic cone, plus a significant component inferred to be arid desert sand dune material infilling the craters. The majority of crater facies deposits at Luxinga contain abundant evidence of water-lain sedimentary units that indicate many of the craters remained open long enough for groundwater to accumulate as deep lakes. We consider the Sossusvlei region of western Namibia to be a close present-day analogy to the environmental setting at Luxinga during kimberlite emplacement.

\begin{tabular}{|c|c|c|c|c|c|c|c|c|}
\hline $\begin{array}{l}\text { Kimberlite } \\
\text { ID }\end{array}$ & $\begin{array}{l}\text { Peak Downhole Magnetic } \\
\text { Susceptibility }\left(\mathrm{SI} \times 10^{-3}\right)\end{array}$ & $\begin{array}{l}\text { AM Anomaly } \\
\text { Intensity (nT) }\end{array}$ & $\begin{array}{l}\text { Facies } \\
\text { Sampled }\end{array}$ & $\begin{array}{c}\text { Geological } \\
\text { Interpretation }\end{array}$ & $\begin{array}{l}\text { Age } \\
(\mathrm{Ma})\end{array}$ & $\begin{array}{l}\text { Error } \\
(\mathrm{Ma})\end{array}$ & Dating Methodology & Dating Laboratory \\
\hline AC139 & 102 & 30 & PK & Vent & 135.7 & \pm 2.1 & Perovskite, ${ }^{206} \mathrm{~Pb} /{ }^{238} \mathrm{U}$. Single Point & Geospec, 2008 \\
\hline $\mathrm{AC1}$ & 55.4 & 1.570 & MK & Lava lake & 145.1 & \pm 4.0 & Perovskite, ${ }^{206} \mathrm{~Pb}{ }^{238} \mathrm{U}$, Single Point & Geospec, 2008 \\
\hline AC39 & 41.9 & 55 & MK & Lava flow & - & - & - & - \\
\hline AC3-32 & 37.7 & 100 & MK & Lava flow & - & - & - & - \\
\hline AC254 & 31.9 & 100 & MK & Sill & 115.5 & \pm 1.1 & Phlogopite, Rb-Sr, Isochron & Geospec, 2008 \\
\hline AC197 & 30.9 & 10 & PK & Vent & 113.0 & \pm 0.8 & Zircon, ${ }^{206} \mathrm{~Pb} /{ }^{238} \mathrm{U}$ Single Point & Gemoc, 2008 \\
\hline AC23 & 30.5 & 60 & PK & Vent & - & - & - & - \\
\hline AC38 & 28.7 & 25 & RVK & Vent & - & - & - & - \\
\hline AC55 & 26.6 & 40 & MK & Sill & 113.0 & \pm 0.8 & Zircon, ${ }^{206} \mathrm{~Pb} /{ }^{238} \mathrm{U}$ Single Point & Gemoc, 2008 \\
\hline AC17 & 25.4 & 5 & MK & Sill & - & - & - & - \\
\hline AC130 & 24.4 & 5 & MK & Vent & - & - & - & - \\
\hline AC22 & 21.5 & 30 & PK & Vent & - & - & - & - \\
\hline
\end{tabular}

Table 1 . Summary geophysical and age data for the 12 bodies with $>20$ SI $\times 10^{-3}$ peak magnetic susceptibility values 


\section{AC3/32}

Drilling of 7 holes at AC3/32 (Fig. 4) delineated a elongate $20 \mathrm{Ha}$ kimberlite body, inferred from its' AM 'footprint' to be $1 \mathrm{~km}$ long by $0.2 \mathrm{~km}$ wide (Fig. $4 \mathrm{~A}$ )

A horizontal unit of aphanitic MK some $3 \mathrm{~m}$ thick on average was intersected at a depth of $50 \mathrm{~m}$ directly underlying unconsolidated Cretaceous Calonda Formation sands, and directly overlying competent Triassic / Jurassic Karoo siltstone bedrock. A basal zone typically $0.5 \mathrm{~m}$ thick is contaminated with occasional angular Karoo siltstone clasts and Karooderived interstitial quartz. The lower contact with the Karoo is generally sharp, with evidence of a baked margin; the upper contact with the Calonda is not well preserved.

It is inferred that the MK material represents a kimberlite lava flow extruded along the flat Karoo palaeo-surface from an unlocated dyke. An alternate emplacement model of a MK sill exposed by preCalonda erosion cannot be excluded, but is considered unlikely given the absence of roof-pendant clasts of Karoo that frequently are present in drill-confirmed kimberlite sills in the Luxinga cluster. Uniformly high magnetic susceptibility (20-30 × $10^{-3}$ SI range) comparable to drill-proven hypabyssal MK sills elsewhere at Luxinga - and the position of the lava flow along the Karoo palaeo-surface indicate that AC3/32 is one of the oldest intrusions at Alto Cuilo.

The AC3/32 body proves that the 'free-to-air' kimberlite eruption surface at about $140 \mathrm{Ma}$ has been preserved in the Luxinga area, and is marked stratigraphically by the uppermost surface of Karoo siltstone that also directly underlies kimberlite.

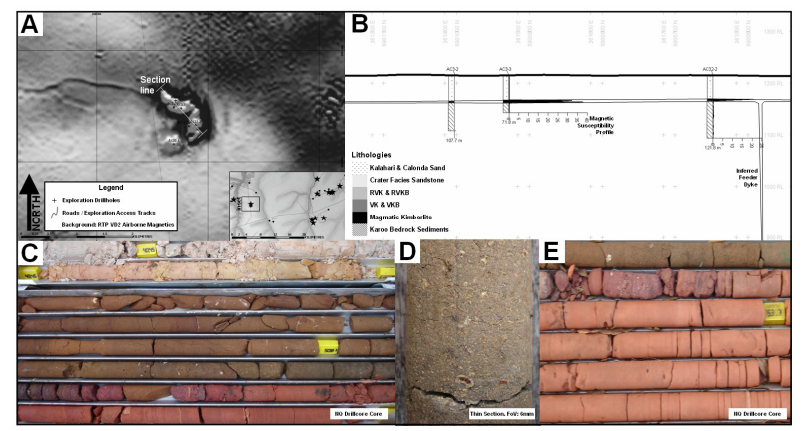

Fig. 4. A: RTP VD2 AM survey map of Kimberlite AC3/32. B: Inferred geological section. C: NQ core from drillhole AC3-3 showing Calonda sands overlying an extrusive MK lava flow that overlies Karoo siltstone. D: NQ drillcore of MK lava at drillhole AC3-3. E: NQ drillcore of MK lava overlying Karoo at AC32-2.

\section{AC1}

Drilling at AC1 (Fig. 5) intersected 100m of Kalahari and Calonda sand overlying 56m of water-lain, highly diluted crater facies sandstone (CFS) sitting directly over a single, homogenous unit of MK to $282 \mathrm{~m}$ depth (eoh) The contact between the CFS and MK is exceptionally well preserved, offering a snapshot of a 'lava-top breccia clasts' being incorporated by crater rim sediments as they slumped to cover what we infer to be a magmatic crater-filling lava lake. The CFS dips parallel to the $30^{0}$ contact, becoming sub-horizontal $3 \mathrm{~m}$ above the MK unit - we interpret this to mark local undulation along a broadly flat MK 'lake surface'. AC1 has been accurately dated to $145 \mathrm{Ma} \pm 4$.0Ma, making it the oldest known intrusion at Alto Cuilo. The MK unit contains thoroughly baked and digested xenoliths indicating the magmatic phase was emplaced at high temperatures, comparable to rootzone hypabyssal kimberlite in Kimberley, South Africa. The unit has uniformly high magnetic susceptibility values, corroborating an independent petrological interpretation that this unit represents "extrusive low energy emplacement" magmatic material.

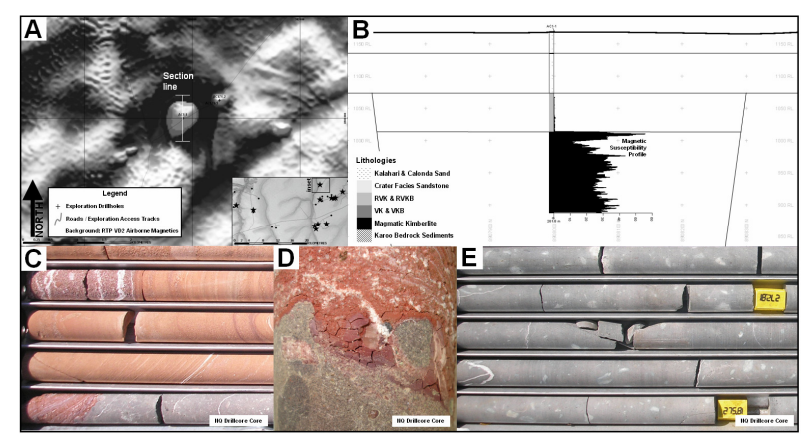

Fig. 5. A: RTP VD2 AM survey map of Kimberlite AC1.

B: Inferred geological section. C \& D: NQ core from drillhole AC1-1 crater facies sandstone contact with magmatic 'lava lake' kimberlite. E: NQ drillcore of massive MK 'lava lake' unit at drillhole AC1-1.

\section{Conclusions}

Kimberlite exploration on the eastern half of the Alto Cuilo concession relied heavily on the high quality AM data that revealed clear magnetic targets against a magnetically quiet background of Karoo siltstone. 31 kimberlites were intersected during a 12 month period. Early observations on the distribution of targets with high AM amplitudes across the concession were corroborated and refined when handheld magnetic susceptibility readings enabled isolation of the geomagnetic characteristics of the kimberlites within the Luxinga cluster. Subsequently, intrusion age data, petrological and petrographic studies, along with stratigraphic and geochemical data for kimberlites across the Alto Cuilo concession has established that intrusion activity commenced at approximately $145 \mathrm{Ma}$ at Luxinga then spread across the whole concession through until 113Ma. Low-energy, shallow intrusive magmatic, and rarer extrusive magmatic lava flows are confined to the Luxinga cluster, pointing to a geographical constraint on kimberlite magma compositions containing lower levels of volatiles that would normally contribute to high-energy explosive eruptions.

\section{References}

Lockhart G., Grütter H.S., Carlson J. Temporal and Geomagnetic Relationship of Ekati Economic Kimberlites. 2004. Lithos 77 (2004) 665- 682

Rogers A, Grütter H, Twidale J, Fractionated megacryst mineral suites from the Luxinga kimberlite cluster, Angola. 9th International Kimberlite Conference Extended Abstract No. 9IKC-A-00174

Skinner E.M.W., Marsh J.S. Distinct Kimberlite Pipe Classes with Contrasting Eruption Processes. 2004. Lithos 76 (2004)183-200 